\title{
Antitumoral and Antioxidant Potential of Egyptian Propolis Against the PC3 Prostate Cancer Cell Line
}

\author{
Elsayed I Salim ${ }^{1 *}$, Afaf D Abd El-Magid², Khalid M Farara ${ }^{3}$, Dina SM Maria ${ }^{1,2}$
}

\begin{abstract}
It has been shown previously that nutritional supplements rich in polyphenolic compounds play a significant role in prostate cancer chemoprevention. Propolis is a natural, resinous hive product that has several pharmacological activities including antimicrobial, antioxidant, anti-inflammatory, and antitumoral activities. The aim of this study was to compare the cytotoxic, antioxidant and antitumoral activities of an ethanolic extract of Egyptian propolis (EEP) in vitro with an established chemotherapeutic drug such as doxorubicin (DOX), and the effects of their combination against the PC3 human prostate cancer cell line. Cellular viability and $\mathrm{IC}_{50}$ levels with EEP, DOX and their (v/v) combination were detected by sulphorhodamine-B (SRB) assay after incubation of $\mathrm{PC} 3$ cells for $72 \mathrm{~h}$ with different doses $(0,0.01,0.1,1,10$ and $100 \mu \mathrm{g} / \mathrm{ml})$. Two selected doses of $\mathrm{IC}_{50}$ and $\mathrm{IC}_{25}$ were applied to cells for $24 \mathrm{~h}$ for antitumor evaluation assay of treatment compounds. EEP and its (v/v) combination with DOX showed significant antitumor potential besides high antioxidant properties of superoxide dismutase (SOD), total antioxidant capacity (TAC), catalase (CAT), nitric oxide (NO) and reduced glutathione (GSH) levels when compared with the control untreated cells. DNA fragmentation assay and semi quantitative RT-PCR analyses for $\mathrm{p53}$ and Bax genes showed that EEP activated cellular apoptosis and increased the mRNA expression levels more than other treatment. In conclusion, EEP alone or in combination with DOX at both doses used here showed greater antioxidant, antiproliferative and apoptotic effects against the PC3 cell lines as compared to treatment with DOX alone. Therefore, EEP could be considered as a promising candidate for prostate cancer chemotherapy.
\end{abstract}

Keywords: Propolis - prostate cancer - PC3 cell line - p53 - Bax - oxidative stress - apoptosis

Asian Pac J Cancer Prev, 16 (17), 7641-7651

\section{Introduction}

The incidence of prostate cancer and its mortality rates are remarkably different in diverse geographic regions and among various racial/ethnic populations, with by far the highest rate in North America and the lowest in Asia (Quinn and Babb, 2002). The incidence of clinical prostate cancer in Arabs is among the lowest in the world. Indeed, this ratio is gradually increasing in the Arab world, particularly in Egypt due to many etiological factors including smoking, intake of high-caloric food, inflammation, aging and the improvement of diagnosis and cancer registration methods (Salim et al., 2011). Clinical trials of adjuvant and neoadjuvant chemotherapies for prostate cancer are recently testing new treatments, and new combinations of treatment. It is of great interest to change cancer therapy from chemotherapy to biotherapy, using biological agents with minimal or no adverse side effects. Many plants and animal extracts have shown various biological activities like immune potentiating and antitumor activities.

Bee propolis extract is one of the most promising candidates for usage as antitumor agent. Propolis is a resinous material collected by bees from bud and exudates of the plants and trees. It is prepared from pollen and transformed by bee enzymes as a gum secretion that varies in color depending on the plant species of origin. Propolis has a long history of being used in traditional medicine back to $300 \mathrm{BC}$. In general, approximately 300 compounds have been identified from propolis (Daugsch, 2008). Most of these belong to three main groups, flavonoids, phenolic acids and esters, and their concentrations vary depending on the ecoflora in the region of collection. The main components subdivisions of propolis are fatty, aliphatic and aromatic acids, flavonoids, alcohols, terpenes, sugars and esters. Moreover, propolis contains many of the B-complex vitamins, important minerals and trace elements. But its bioflavanoid content is now receiving attention. Propolis from the Mediterranean region is known to possess flavonoids, esters of caffeic and ferulic acids considering that the hydro-alcoholic extract was the most effective (Abozid and Ahmed, 2013).

Previously, Abd El Hady and Hegazi, (1994) found that the Egyptian propolis constituents are phenolic acid esters 
Elsayed I Salim et al

(72.7\%), phenolic acids (1.1\%), aliphatic acids $(2.4 \%)$, dihydrochalcones $(6.5 \%)$, Chalcones $(1.7 \%)$, flavanones $(1.9 \%)$, flavones $(4.6 \%)$ and tetrahydrofuran derivatives $(0.7 \%)$. It was clear that phenolic acid esters are present in a major quantity $(72.7 \%)$. These results revealed that Egyptian propolis is characterized by the presence of unusual esters of caffeic acid with C12-C16 fatty alcohols which are mainly saturated. Also flavonoid aglycones and especially flavanones are typical components of Egyptian propolis. Previously et al. (2000) identified a series of triterpenes in Egyptian propolis, including the characteristic animal sterol precursor, lanosterol. Also, Egyptian propolis was found to contain some enzymes such as succinic dehydrogenase, glucose-6-phosphatase, adenosine triphosphatase and acid phosphatase (Abozid and Ahmed, 2013).

Propolis has been the subject of scientific interest for its diverse range of biological properties, including anti-inflammatory and immunomodulatory (Orsatti et al., 2010), anti-carcinogenic (Szliszka et al., 2011), antioxidant (Teixeira et al., 2010), antibacterial, antiviral and antifungal effects (Kujumgiev et al., 1999). Flavonoids such as those found in propolis have been reported to induce apoptotic cell death in various cancer cell lines including a variety of leukemic cell lines, but sparing the normal non cancer cells during the process of DNA replication, transcription, and recombination. Previously, propolis showed strong anti-free radical activity, which resulted from the components in propolis including caffeic acid, ferulic acid and caffeic acid phenethyl ester (CAPE) (Kumazawa et al., 2004).

The anti-cancer activities of propolis have been presented in various culture cell lines, such as mammary carcinoma (MCA), human epithelial carcinoma (HeLa), human leukemia (HL-60, CI41, U937), human ovarian carcinoma (SK-OV-3), human lung carcinoma (NCI-H358), human hepatocellular carcinoma (HepG2), human cervical cancer (ME180) and human pancreatic cancer (PANC-1, BxPC-3) cells (Chen et al., 2008). Also, propolis and its polyphenolic compounds exerted considerable cytotoxicity, without cross-resistance, in both wild-type and chemo-resistant human tumor cell lines besides an anti-metastatic and antitumor effect in mice and rats (Orsolic, 2010). Also CAPE-induced apoptosis in HL-60 cells was associated with GSH depletion and scavenging of hydrogen peroxide (Chen et al., 2007). On the in vivo level, propolis its flavonoids and CAPE have been found to inhibit the development of chemicallyinduced carcinogenesis in animal models particularly those of lung, oral, oesophageal, stomach, colon, skin, prostate and mammary cancers (Orsolic et al., 2008).

Doxorubicin belongs to the anthracyclines family and is one of the most widely used anti-tumor antibiotics, isolated from different Streptomyces species. Its usefulness as a chemotherapeutic agent stews from its broad spectrum of antitumoral activity for the treatment of a variety carcinomas, soft tissue cancer, bone sarcomas and hematogenous neoplasms (Hilger et al., 2005). Chemotherapy, despite many side effects, is still the most popular way of treating cancer. The induction of apoptosis in tumor cells is considered very useful in the management and the therapy as well as in the prevention of cancer (Yong et al., 2013).

It is known that the tumor suppressor gene p53 is the main proapoptotic gene triggering DNA repair or apoptosis mechanisms. p53 gene has been implicated also in the activation pathways of various cell cycle checkpoints like the G1/S and G2/M transitions (Taraswi et al., 2009). Also, Bax gene is a pro-apoptotic member of the Bcl-2 family, which is the best characterized mediator of p53 dependent apoptosis. Bax translocates from the cytosol to mitochondria and causes activation of the Caspase cascade by releasing cytochrome $\mathrm{C}$ from the inter-membrane space (Adams et al., 1998). The activation of Caspases is a final commitment step for apoptosis.

Therefore, the present work was aimed to study the possible antitumor activity of the Egyptian propolis against prostate cancer PC3 cell lines and to compare its activity with a reference chemotherapeutic drug, doxorubicin. Also, the efficacy of the combination therapy of the Egyptian propolis and doxorubicin was evaluated and was compared with that of each treatment alone. Moreover, the study evaluated the underlying mechanisms predisposing to the antitumor activities of propolis, doxorubicin and their combination using biochemical and molecular genetic parameters and estimated whether the genetic information could be used to better tailor therapies for prostate cancer treatment.

\section{Materials and Methods}

\section{Propolis samples and ethanolic extracts}

Egyptian propolis was collected by transparent glass slide plaques from honey bee colonies located in the apiary of Beekeeping Research Section, Plant Protection Research Institute, Agriculture Research Centre at Dokki, Giza, Egypt. propolis was used fresh at room temperature ranging between $20-24{ }^{\circ} \mathrm{C}$ for ethanolic extracts preparation. Briefly, propolis samples were macerated in the proportion of 10 grams to $100 \mathrm{ml}$ of the solvent (ethanol $80 \% \mathrm{v} / \mathrm{v}$ ) with occasional shaking. Extracts were obtained after 7 days of maceration, filtered and then incubated at room temperature until ethanol was evaporated and the product obtained a honey-like consistence which is referred to as Ethanolic Extract of Propolis (EEP). This method was previously reported by (Begnini et al, 2014).

\section{Cell line and cell culture}

The human PC3 prostatic cancer cell line was obtained from Egyptian products and vaccines, sera and drugs (Vaccera) (Giza, Egypt), originally obtained from the American Type Culture Collection (ATCC, CRL-1435). These cells exhibit low acid phosphates and testosterone -5-alpha reductase activities. Cells were grown in monolayer cultures in Roswell Park Memorial Institute medium, RPMI-1640, (PAA - cell culture company, Germany through Immuniq, Poland) supplemented with $10 \%$ fetal bovine serum, $4 \mathrm{mML}$-glutamine, $100 \mathrm{U} / \mathrm{ml}$ penicillin and $100 \mu \mathrm{g} / \mathrm{ml}$ streptomycin), $5 \%$ (v/v) $\mathrm{CO}_{2}$ atmosphere at $37^{\circ} \mathrm{C}$. 
Cytotoxicity assays by sulphorhodamine-B (SRB) method

Cell survival was determined using SRB method as previously described by (Skehan et al., 1990). Different concentrations of the test compounds (Doxorubicin $(\mathrm{DOX})$, Ethanolic extract of propolis (EEP) and combination of both DOX and EEP at a (v/v) concentration of both) were incubated for $72 \mathrm{hrs}$ with the cell monolayer triplicate wells prepared for each individual dose with various concentrations of drugs (the stock solution was at concentration of $100 \mathrm{Mm}$, then 10 fold serial dilutions) $(0.01,0.1,1.0,10.0,100.0 \mu \mathrm{g} / \mathrm{ml})$ and $(0.0 \mu \mathrm{g} / \mathrm{ml})$ as control). The percentage of viable cells was determined using the equation below: Viability $(\%)=($ No. of viable cells x 100) divided by Total No. of cells).

\section{Determination of $I C_{50}$}

The optical density (OD) of each well was measured spectrophometrically at 545 and $540 \mathrm{~nm}$ with an ELIZA micro plate reader. The $\mathrm{IC}_{50}$ values were calculated using sigmoidal concentration response curve fitting models (sigmaplot software). The percent of cytotoxicity was calculated by the formula, percent cytotoxicity = [1-(absorbance of experimental wells/absorbance of control wells)] x 100 .

\section{The experimental plan}

The three treatment compounds namely, Doxorubicin (DOX), Ethanolic extract of propolis (EEP) and Combination of both DOX and EEP at a (v/v) concentration, were added to the media at two concentrations; $\mathrm{IC}_{25}$ and $\mathrm{IC}_{50} \mu \mathrm{M}$ which was obtained from the previous step (cytotoxicity assay). Untreated PC3 cells were regarded as negative control. After $24 \mathrm{hrs}$ of incubation at $37^{\circ} \mathrm{C}$ in an atmosphere containing $5 \% \mathrm{CO}_{2}$, the cells were collected in sterile $15 \mathrm{ml}$ tubes and the cells were washed twice using ice cold 1x PBS, washing solution was also added to the same $15 \mathrm{ml}$ tube centrifuged at $3000 \mathrm{rpm}$ for $10 \mathrm{~min}$. The supernatant was removed, the cell pellet was washed twice by suspension in $1 \mathrm{ml}$ ice cold PBS in $1.5-\mathrm{ml}$ micro centrifuge tubes and centrifuged at 4000 $\mathrm{rpm}$ for $5 \mathrm{~min}$ at $4{ }^{\circ} \mathrm{C}$ between washes. The supernatant was removed, and the rest of pellets were taken for antioxidant and molecular techniques. Some cells were fixed with $4 \%$ formaldehyde solution for $30 \mathrm{~min}$ in PBS for determination of morphological changes and photography using an inverted microscope at 400X. The experiment was repeated in duplicate to confirm results.

\section{Determination of the antioxidant activity levels}

SOD activity was determined in untreated and treated PC 3 cells according to the method described by Shiraishi et al. (2005). TAC activity was determined according to the method described by the manufacture's kit (Abnova, Walnut, CA. 91788, USA). Catalase activity was determined according to the method described by Sinha, (1972). Nitric oxide concentration was colorimetrically determined by Nitrite Assay Kit (Biodiagnostic, Egypt) according to the method described by Montgomery and Hum, (1995). Reduced glutathione (GSH) concentration was colorimetrically determined according to the method described by Beutler et al., (1988).

\section{DNA extraction \& DNA fragmentation assay}

The cells from all the groups were resuspended in $0.5 \mathrm{ml}$ lysis buffer, incubated for $1.5 \mathrm{hrs}$ in $37^{\circ} \mathrm{C}$ then centrifuged at $14,000 \mathrm{rpm} / \mathrm{RT} / 5 \mathrm{~min}$. The Supernatants were transferred into new tubes and equal volume of isopropanol and $25 \mathrm{ml}$ $4 \mathrm{M} \mathrm{NaCl}$ (100 mM final concentration) were added. Tubes were incubated overnight at $-20^{\circ} \mathrm{C}$ then centrifuged again at 14,000 rpm/RT/20-25 min. Afterwards, the DNA pellets were dissolved in $30-50 \mathrm{ml}$ ddH2O with 1-2 ml RNase. After $1 \mathrm{hr}$ of $37^{\circ} \mathrm{C}$ incubation, the DNA concentration was measured spectrophotometrically and $5 \mu \mathrm{lDNA} /$ lane were run on $1 \%$ agrose gel to determine the DNA fragmentation levels (Samarghandian and Shabestari, 2013).

\section{RNA isolation}

RNA was extracted from treated and untreated PC3 cells post 24 treatments using Qiagene kit according to the manufacturer's protocol (OneStep RT-PCR kit, Qiagne, Valencia, CA). Extracted RNA was stored at $-80{ }^{\circ} \mathrm{C}$ and concentration and purity of the extracted RNA were determined where RNA was diluted with distilled water and the optical density was measured spectrophotometrically at 260 and $280 \mathrm{~nm}$. RNA concentration and purity were calculated as follows: Concentration of the extracted RNA $(\mu \mathrm{g} / \mathrm{ml})=\mathrm{A} 260 \mathrm{X}$ dilution factor X 40 RNA purity = A260 /A280.

\section{Semi-quantitave RT-PCR analysis}

For each sample, extracted RNA (1 $\mu \mathrm{g})$, random hexamer primer $(1 \mu \mathrm{l})$ and DEPC-treated water (to 12 $\mu 1)$ were mixed, vortexed briefly and incubated at $65^{\circ} \mathrm{C}$ for $5 \mathrm{~min}$. Samples were placed on ice and the cDNA was synthesized using RvertAid H Minus Reverse transcriptase $(200 \mathrm{u} / \mu \mathrm{l})$ where Samples were mixed gently, centrifuged and incubated at $25^{\circ} \mathrm{C}$ for $5 \mathrm{~min}$ followed by $42^{\circ} \mathrm{C}$ for $60 \mathrm{~min}$. Reaction products (cDNA) were stored frozen at $-80{ }^{\circ} \mathrm{C}$. The synthesis of cDNA was verified using GAPDH specific control primers. PCR was performed and RT-PCR product $(10 \mu \mathrm{l})$ was loaded on $1.5 \%$ agarose gel and bands were visualized by gel documentation system. Evaluating the expression of p53 and Bax genes was carried out using the newly synthesized cDNA as templates for PCR. Twenty five $\mu 1$ Qiagen Taq green master mix, $4 \mu \mathrm{l}$ cDNA, $2 \mu \mathrm{l}$ forward primer (10 picomole $/ \mu \mathrm{l}), 2 \mu \mathrm{l}$ reverse primer (10 picomole $/ \mu \mathrm{l}$ ) and $17 \mu \mathrm{l}$ nuclease free water were pre-denaturated at $94^{\circ} \mathrm{C}$ for $3 \mathrm{~min}$. Amplification was performed ( 35 cycles). Non-reverse transcribed RNAs were included to confirm the absence of genomic DNA. Negative control without adding template was also included to assess for reagent contamination.

PCR was carried out in duplicate followed by denstiometric analysis of band intensities using gel documentation system. Data representing mRNA expression levels of p53 and Bax were calculated in comparison to GAPDH as the mean ratio of band intensities \pm standard deviation and plotted against test concentrations and time intervals. Statistical significance was carried out using one way t-test. Primer sequences and the PCR product size are shown in Table (1). 


\section{Results}

SRB assay of cytotoxicity ( $I C_{50}$ assay):

The survival fraction (viability\%) assay was used as indicator for cell cytotoxicity for PC3 cell lines treated with serial concentrations of $0,0.01,0.1,1,10$ and 100 $\mu \mathrm{g} / \mathrm{ml}$ respectively of DOX, EEP and combination of both compounds for $72 \mathrm{hrs}$ are shown in Figure (1, a-c). The results showed that the percentage of survival cells decreased along with the increase of DOX, EEP and combined treatments concentrations in a dose dependent manner. It was estimated from Figure (1) that the inhibition concentrations $\left(\mathrm{IC}_{50}\right)$ calculated from the DOX, EEP and combined treatments were $0.738,38.48$ and $0.27 \mu \mathrm{g} / \mathrm{ml}$ respectively.

Treatment of PC3 cells with different compounds at $I C_{50}$ $\& I C_{25}$ doses for $24 \mathrm{hrs}$

Morphological changes: Figure (2) shows that the treatment with high doses of DOX, EEP and their combination at $\mathrm{IC}_{50}$ doses $(0.738,38.48 \mu \mathrm{g} / \mathrm{ml}$ and 0.27 $\mu \mathrm{g} / \mathrm{ml} \mu \mathrm{g} / \mathrm{ml}$ respectively) exerted more prominent morphological changes than those seen after treatment

Table 1. Primer Sequences of p35, Bax and GAPDH

\begin{tabular}{|c|c|c|}
\hline Gene & Primer sequences & $\begin{array}{l}\text { Size of PCR } \\
\text { product (bp) }\end{array}$ \\
\hline \multirow{2}{*}{ p53 } & $\begin{array}{c}\text { F: } 5 \text {-CCA GAT CTT AGC GCC } \\
\text { GAG CCC-3 }\end{array}$ & \multirow{2}{*}{438} \\
\hline & $\begin{array}{c}\text { R: } 5 \text {-GCG TGT GGA ATC AAC } \\
\text { CGA CAG-3` }\end{array}$ & \\
\hline \multirow{2}{*}{ Bax } & $\begin{array}{c}\text { F: } 5 \text {-ATG GCC GGG TCC GCG } \\
\text { GAG CA-3 }\end{array}$ & \multirow{2}{*}{322} \\
\hline & $\begin{array}{c}\text { R: } 5 \text {-CCC AGT TGA AGT TGC } \\
\text { CGT CA-3` }\end{array}$ & \\
\hline \multirow{2}{*}{ GAPDH } & $\begin{array}{c}\text { F: } 5 \text {-CAA GCT CAT CCA TGA } \\
\text { CTA CTT - } 3\end{array}$ & \multirow{2}{*}{496} \\
\hline & $\begin{array}{c}\text { R: } 5 \text {-GAC CAC CAC CCT GCT } \\
\text { GCT GTA - } 3 \text { ' }\end{array}$ & \\
\hline
\end{tabular}

Where, F: Forward; R: Reverse with their corresponding low doses of $\mathrm{IC}_{25}$ compared to the control cells. The most obvious morphological changes were observed with PC3 cells treated with the v/v combination of DOX and EEP at the dose of $\mathrm{IC}_{50}(0.27$ $\mu \mathrm{g} / \mathrm{ml})$. These morphological changes were obvious after 24 hrs of treatment.

Generally, the morphology of PC3 cells treated with DOX, EEP and v/v combination of both compounds showed abnormal appearance comparing to untreated control cells, these changes were mainly confined to apoptotic and cytotoxic changes to the cells. In general, these changes were obvious when treated cells started to show gradual cell shrinkage, cell rounding, detaching from the surface of tissue culture flasks and floating in the tissue culture medium, and finally they showed obvious cell swelling and rupture.

\section{Oxidative stress markers}

Treatment of PC3 cells with EEP, DOX or v/v combination of both using two concentrations, $\mathrm{IC}_{25}$ and $\mathrm{IC}_{50}$, exhibited differences in the SOD activity levels after $24 \mathrm{~h}$ of incubation as compared to the control (Table 2).

Superoxide dismutase (SOD) activity levels: Treatment with EEP at $\mathrm{IC}_{25}$ dose showed a significant increase in SOD activity, while treatment with EEP at $\mathrm{IC}_{50}$ dose exhibited a significant decrease as compared with the control. However, a significant decrease in SOD activity was observed in DOX-treated group at $\mathrm{IC}_{50}$ dose. The DOX $\mathrm{IC}_{25}$ dose-treated group showed no significant differences in SOD levels as compared to the controls. Combination between DOX and EEP with the concentration dose of $\mathrm{IC}_{25}$ exhibited a significant increase of SOD activity as compared to control levels, while treatment with the dose of $\mathrm{IC}_{50}$ exhibited a significant decrease in SOD activity (Table 2).

Total antioxidant capacity levels: The obtained data in (Table 2) showed that treatment of PC3 cells with EEP with the dose $\mathrm{IC}_{25}$ exhibited significant increase in the total antioxidant capacity (TAC) concentration levels after $24 \mathrm{~h}$ of incubation as compared with the control group. A significant decrease was observed in the group treated with the dose $\mathrm{IC}_{50}$ of EEP as compared to normal controls. Furthermore, a significant decrease in TAC

Table 2. Least Square Means \pm Standard Errors (LSM \pm SE) of SOD, TAC, CAT, NO and GSH Activities of PC3 Cells Treated with Ethanolic Extract of Propolis, Doxorubicin and Combination of Both of Them for $24 \mathrm{hrs}$

\begin{tabular}{|c|c|c|c|c|c|c|}
\hline $\begin{array}{l}\text { Group } \\
\text { no. }\end{array}$ & Treatment & SOD (U/g) & TAC (nmol/g) & $\begin{array}{l}\text { CAT activity } \\
(\mathrm{nmol} / \mathrm{g})\end{array}$ & NO conc. $(\mathrm{nmol} / \mathrm{g})$ & $\begin{array}{l}\text { GSH conc } \\
\text { (ng/g tissue) }\end{array}$ \\
\hline G1 & Control cells & $33.33 \pm 0.85$ & $7.44 \pm 0.37$ & $52.58 \pm 0.68$ & $103.07 \pm 0.71$ & $5.63 \pm 0.43$ \\
\hline G2 & $\mathrm{EEP} \mathrm{IC}_{25}$ & $35.64 \pm 0.60 * a b$ & $8.99 \pm 0.278 * a b$ & $65.62 \pm 0.42 * a b$ & $130.80 \pm 0.89 * a b$ & $5.35 \pm 0.45$ \\
\hline G3 & $\mathrm{EEP} \mathrm{IC}_{50}$ & $28.09 \pm 0.68 * a b$ & $5.28 \pm 0.29 * b$ & $41.75 \pm 0.72 * a b$ & $86.63 \pm 0.49 *$ & $8.53 \pm 0.44 * a b$ \\
\hline G4 & $\mathrm{DOX} \mathrm{IC}_{25}$ & $32.15 \pm 0.78 * a$ & $5.78 \pm 0.18 *$ & $37.27 \pm 0.68 * a$ & $61.21 \pm 0.43 *$ & $8.71 \pm 0.38 * a b$ \\
\hline G5 & $\mathrm{DOX} \mathrm{IC}_{50}$ & $25.34 \pm 0.85 * \mathrm{a}$ & $4.35 \pm 0.29 *$ & $35.99 \pm 0.58 *$ & $44.50 \pm 0.50 * b$ & $3.59 \pm 0.24 *$ \\
\hline G6 & DOX +EEP IC ${ }_{25}$ & $40.80 \pm 0.78 * a b$ & $8.32 \pm 0.29 *$ & $57.34 \pm 0.44 * a$ & $91.46 \pm 0.72 *$ & $6.16 \pm 0.44 *$ \\
\hline G7 & $\mathrm{DOX}_{+} \mathrm{EEP} \mathrm{IC}_{50}$ & $26.83 \pm 0.059 * \mathrm{a}$ & $6.03 \pm 0.18 *$ & $46.21 \pm 0.45 * \mathrm{a}$ & $71.62 \pm 0.34 *$ & $2.69 \pm 0.22 *$ \\
\hline
\end{tabular}

*Significantly different as compared to the untreated control group. a: Significantly different from all the other treatment groups except that of group (6) only at the case of TAC. b: Levels of treatment compounds with the same concentrations are significantly different except between groups (2 and 6) only in the case of TAC . Significance level is at P<0.05. EEP: Ethanolic Extract of Propolis, DOX: Doxorubicin 

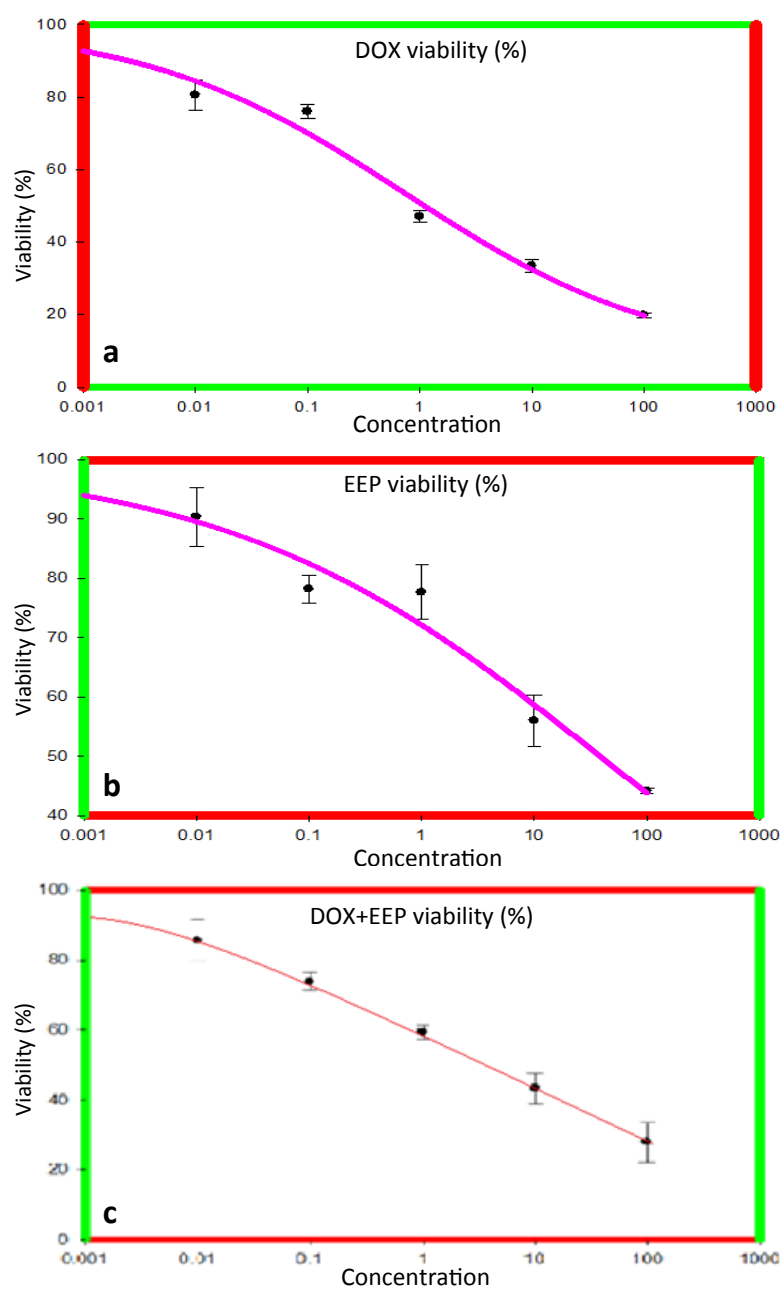

Figure 1. (a-c): The Cytotoxicity of the (v/v) Combination of DOX (a), EEP (b) and EEP + DOX (c) on PC3 Cells. The cancer cells were incubated for $72 \mathrm{hrs}$ with the EEP + DOX at different concentrations. The percentage of dead cells was measured by SRB cytotoxicity assay. DOX: Doxorubicin; EEP: Ethanolic Extract of Propolis

levels was observed in the DOX-treated group with both doses $\mathrm{IC}_{50}$ and $\mathrm{IC}_{25}$ as compared to the controls. Also the $\mathrm{v} / \mathrm{v}$ combination of DOX and EEP at the concentration level of $\mathrm{IC}_{50}$ exerted significant decrease in TAC levels as compared to the controls and to the $\mathrm{IC}_{50}$-trated group. In the same time, it was observed that the combination of both DOX and EEP at the dose $\mathrm{IC}_{25}$ exhibited increasing levels as compared to the control values.

Catalase activity levels: Table (2) shows that the treatment of PC 3 cells with EEP only with a concentration dose of $\mathrm{IC}_{25}$ exhibited a significant increase in catalase (CAT) activity levels after $24 \mathrm{~h}$ of incubation as compared with the control cells. Treatment of cells with the concentration dose $\mathrm{IC}_{50}$ showed a significant decrease in CAT levels as compared to all groups except that of group (6). Furthermore a significant decrease in CAT activities was also observed in doxorubicin group treated with $\mathrm{IC}_{50}$ and $\mathrm{IC}_{25}$ doses respectively. Treatment with the v/v combination of DOX and EEP at the dose of $\mathrm{IC}_{25}$ exhibited a significant increase in CAT activity, while that with the dose $\mathrm{IC}_{50}$ exhibited a significant decrease in CAT activity levels as compared to the controls levels.

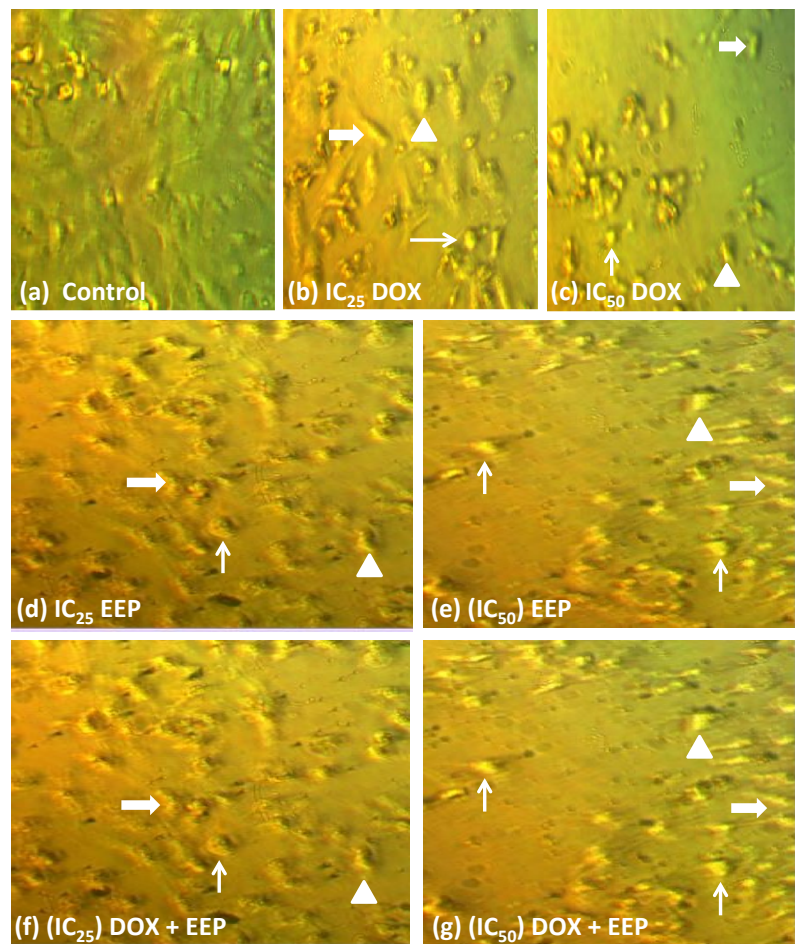

Figure 2. Morphological Changes of PC3 Cells Treated for 24 hrs with DOX, EEP or Combination of Both: (a) Control Untreated PC3 Cells; (b) Cells Treated with $\mathrm{IC}_{25}$ of DOX, (c) Cells Treated with $\mathrm{IC}_{50}$ of DOX; (d) Cells Treated with IC25 of EEP, (e) Cells Treated with $\mathrm{IC}_{50}$ of EEP, (f) Cells Treated with $\mathrm{IC}_{25}$ of combination, (g) Cells Treated with $\mathrm{IC}_{\mathbf{5 0}}$ of Combination. Note cell rounding (thin arrows), cell shrinkage (thick arrows) and cell swelling (arrow heads). DOX: Doxorubicin; EEP: Ethanolic Extract of Propolis

Nitic oxide (NO) levels: The treatment with the EEP with the concentration of $\mathrm{IC}_{25}$ exhibited a significant increase in nitric oxide NO levels after $24 \mathrm{~h}$ incubation as compared to the control group. In contrast, the levels of NO levels in PC3 cells treated with $\mathrm{IC}_{50}$ dose of EEP exhibited a significant decrease. Further, a dose dependent significant decrease in NO concentrations levels was observed in all the other treatment groups, with the lowest level detected after treatment with the DOX $\mathrm{IC}_{50}$ dose as compared to all other treatment groups (Table 2).

Glutathione reductase (GSH) levels: The treatment with EEP with concentration of $\mathrm{IC}_{50}$ exhibited a significant increase in GSH levels after $24 \mathrm{hrs}$ incubation period as compared with the control. In contrast, no significant levels were obtained when cells were treated with $\mathrm{IC}_{25}$ dose of EEP as compared to the control. On the other hand, a significant increase in the GSH concentration levels was observed in the group treated with DOX at the dose level of $\mathrm{IC}_{25}$, while a significant decrease was obtained when treated with the $\mathrm{IC}_{50}$ dose as compared to the control. Combination between DOX and EEP at $\mathrm{IC}_{25}$ dose level exhibited no significant differences in GSH concentration levels, while treatment with both compound at concentration of $\mathrm{IC}_{50}$ exhibited a significant decrease in GSH levels as compared to controls. The highest GSH 


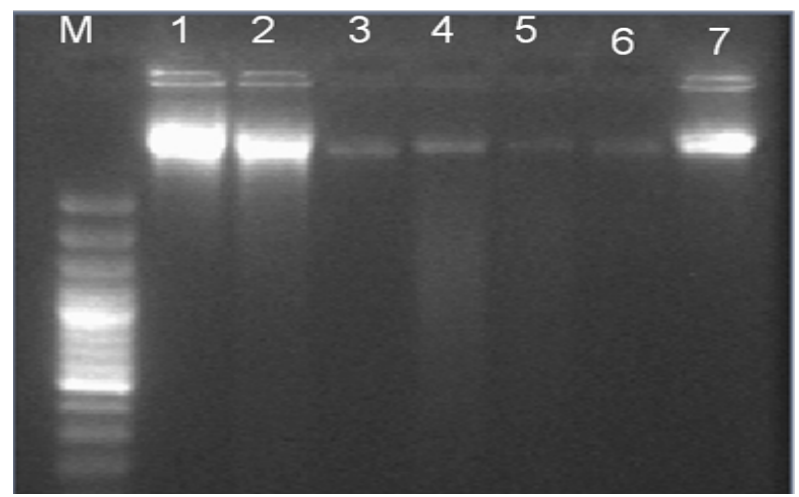

Figure 3. Photograph of Agarose Gel DNA Fragmentation Electrophoretic Analysis of DNA Isolated from PC3 Cells, Treated or Untreated with Different Concentrations of DOX, EEP and Combination of Both for $\mathbf{2 4}$ hrs. Lane M: Marker (DNA ladder); Lane 1: Control, Lane 2: DOX IC50 $(0.738 \mu \mathrm{g} / \mathrm{ml})$; Lane 3: DOX IC25 $(0.369 \mu \mathrm{g} / \mathrm{ml})$; Lane 4: EEP IC50 $(38.48 \mu \mathrm{g} / \mathrm{ml})$; Lane 5: EEPIC25 (19.24 $\mu \mathrm{g} / \mathrm{ml})$, Lane 6: DOX+EEPIC50 (0.27 $\mu \mathrm{g} / \mathrm{ml})$; Lane 7: DOX+EEP IC25 $(0.135 \mu \mathrm{g} / \mathrm{ml})$

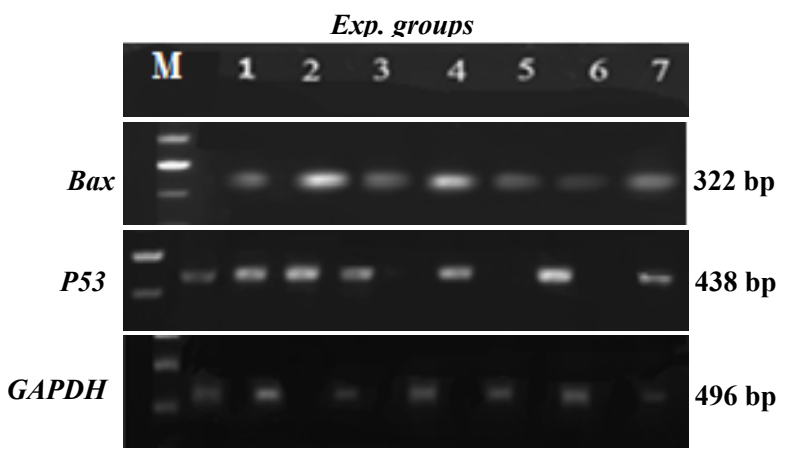

Figure 4. Positive Signals of mRNA Expression of p53 and Bax genes from Treated and Untreated PC3 Cells after 24hrs Incubation. Where: M, Marker; 1-7: Experimental groups: 1, Untreated cells. 2, DOX $\left(\mathrm{IC}_{50}\right) ; 3$, EEP $\left(\mathrm{IC}_{50}\right) ; 4, \mathrm{DOX}+\mathrm{EEP}\left(\mathrm{IC}_{50}\right) ; 5, \mathrm{DOX}\left(\mathrm{IC}_{25}\right) ; 6, \mathrm{EEP}\left(\mathrm{IC}_{25}\right) ; 7$, DOX+EEP ( $\left(\mathrm{IC}_{25}\right)$. DOX: Doxorubicin, EEP: Ethanolic Extract of Propolis

levels were obtained after treatment with $\mathrm{DOX}\left(\mathrm{IC}_{25}\right), \mathrm{EEP}$ $\left(\mathrm{IC}_{50}\right)$ and DOX+EEP $\left(\mathrm{IC}_{25}\right)$ (Table 2).

\section{DNA fragmentation assay}

To detect the possible relationship of the potential of treatment compounds, DOX, EEP and combination of both of them against PC3 cells on programmed cell death as a mechanism of action, DNA fragmentation assay was carried out. DNA gel electrophoresis (Figure 3) clearly showed that the untreated cells at lane (1) had least DNA breakdown or fragmentation as compared to all the other treatment groups. The DNA of treated cells showed obvious breakdown which appeared fragmented as compared to the control. It sometimes appeared as a mild smear of very small fragments of DNA.

\section{Semi-quantitave RT-PCR analysis}

The expression profile of the p53 and Bax genes against PC3 cells either untreated or treated with $\mathrm{IC}_{50}$ and $\mathrm{IC}_{25}$ doses of DOX, EEP and their combination were estimated using semi-quantitative RT-PCR analysis.

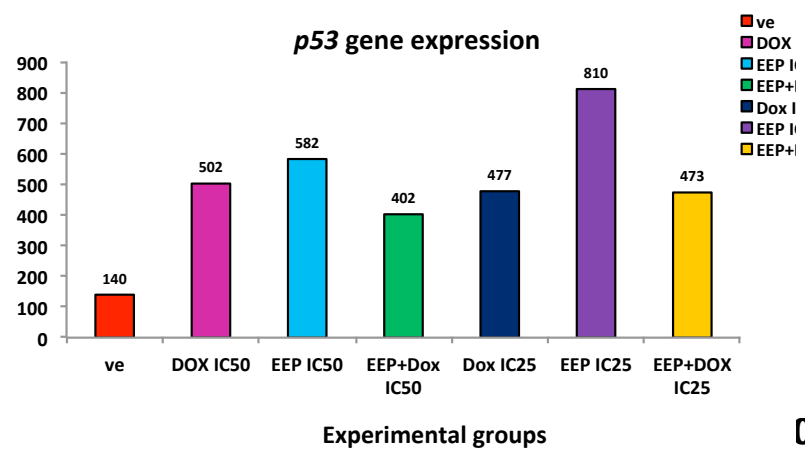

Figure 5. p53 mRNA Expression levels for PC3 cells Treated with Different Compounds after Normalization with the Internal Control gene GAPDH. DOX: Doxorubicin, EEP: Ethanolic Extract of Propolis

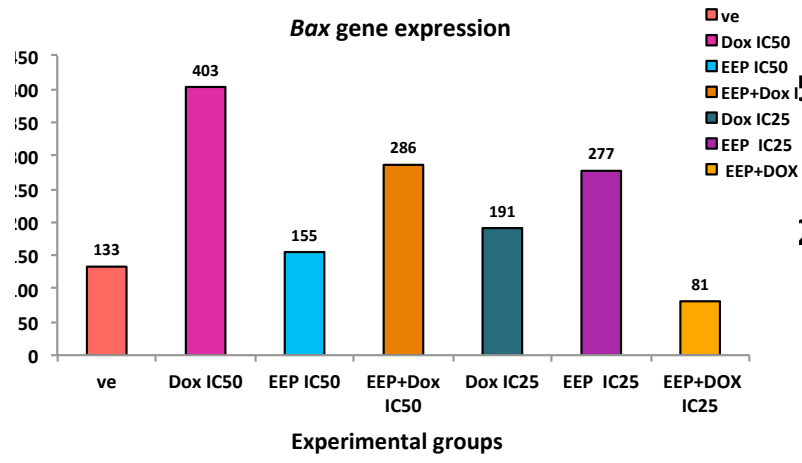

Figure 6. Bax mRNA Expression Levels for PC3 Cells Treated with Different Compounds after Normalization with the Internal Control gene GAPDH. DOX: Doxorubicin, EEP: Ethanolic Extract of Propolis

Characterization of GAPDH gene was utilized as internal control to be compared and neutralized with the mRNA expression values of p53 and Bax to evaluate their efficiency in treated or untreated cells. The positive signals at the proper size of all studied genes are shown in Figure (4).

p53 mRNA gene expression: cDNA PCR product of proper size (438 bp) was detected in lanes 1, 2, 3, 4, 5, 6 and 7 (Figure 4). Figure (5) shows the p53 mRNA expression data after normalization with the expression data of the internal control gene, GAPDH. The figure shows that all treatment doses caused a marked overexpression of p53 mRNA after $24 \mathrm{hrs}$ of incubation. EEP at both doses of $\mathrm{IC}_{25}$ and $\mathrm{IC}_{50}$ have markedly up-regulated the mRNA expression levels of the p53 gene more than all other treatment compounds (Figure 5).

Bax mRNA gene expression: mRNA Expression of Bax gene in PC3 cells untreated and treated with $\mathrm{IC}_{50}$ and $\mathrm{IC}_{25}$ doses of DOX, EEP and their combination are shown in Figures $(4,6)$. All treatment compounds at all dose levels except that of DOX+ EEP at $\mathrm{IC}_{25}$ doses have exerted a marked increase in the Bax gene mRNA expression as detected after the normalization with the data of the internal control gene, GAPDH (Figure 6). The highest Bax gene expression levels were detected in DOX $\mathrm{IC}_{50}, \mathrm{EEP}+\mathrm{DOX} \mathrm{IC}_{50}$ and EEP at $\mathrm{IC}_{25}$ doses respectively as compared to the other treatment compounds. 


\section{Discussion}

Natural products continue to be an excellent and reliable source for the development an inexpensive resource of anticancer drug discovery (Kasala et al., 2015). Propolis and its compounds possess strong antitumor potential (Chan et al., 2013). Many reports have indicated that different types of propolis extracts significantly inhibit cell growth and reduce the differentiation or proliferation of tumor cells (Khalil, 2006). In the present study we evaluated the cytotoxicity of ethanolic extract of propolis (EEP) on PC3 prostate cancer cell line using the SRB assay as an end point marker for detection. Our in vitro data herein demonstrated that treatment with EEP resulted in cellular morphological changes, significant anti-proliferative effects, besides cytotoxic effects in the prostate cancer cell lines. Interestingly, our results have also shown that the percentage of survival cells was decreased with increase of EEP concentrations in a dose dependent manner. These data indicate a strong effectiveness of the EEP extract against prostate cell line PC3. Also treated PC3 cells with chemotherapy such as doxorubicin (DOX) have shown that the percentage of survival cells was decreased with the increase of DOX concentration, while the combination of both DOX and EEP have shown that the percentage of survival cells was decreased with the increase of doses of combination. These results are in line with those of Szliszka et al. (2011) who reported that administration of $50 \mu \mathrm{g} / \mathrm{mL}$ EEP from southern Poland exhibited $25 \%$ cytotoxicity in prostate cancer cells. Also, Vatansever et al. (2010) have shown previously that EEP at a concentration of $125 \mu \mathrm{g} / \mathrm{mL}$ is cytotoxic to MCF-7 breast cancer cell lines. They also reported differences in the cytotoxic effects on MCF-7 cells after administration of seven different EEP samples collected from different locations. On the other hand, propolis exhibited antitumor activity in mature mice bearing Ehrlich carcinoma (Scheller et al., 1989).

The antitumor activity of propolis could be due to the presence of a variety of compounds considered to be the most promising of the antitumour agents including caffeic acid (CA), caffeic acid phenethyl ester (CAPE), artepillin $\mathrm{C}$, quercetin, naringenin, resveratrol, galangin, genistein, plukenetione A and others. CAPE possesses various therapeutic effects including antimicrobial, antioxidant anti-inflammatory and cytotoxic properties (Murtaza et al., 2014). Artepillin C was also isolated from Brazilian propolis which exhibited preferential cytotoxic activity against tumor cells cultured in vitro (Kimoto et al., 2001). CAPE treatments have been shown to sensitize cancer cells to chemotherapeutic drugs and radiation treatment by inhibiting pathways that lead to treatment resistance in animal models (Akyol et al., 2012). CAPE is a protective agent from therapy-associated toxicities in animal models.

Doxorubicin is a chemotherapy drug used for hematological malignancies with side effects including acute renal failure (Akyol et al., 2014). CAPE treatment protected renal, heart, and brain tissues damages caused by doxorubicin administration in rats (Yagmurca et al., 2004). The ability of flavonoids isolated from propolis to
Antitumor Effects of Propolis Against PC3 Prostate Cancer Cells prevent the toxicity of some drugs such as cisplatin and doxorubicin was documented previously (Orsolic et al., 2008). Chen et al. (2008) have demonstrated that two new prenyl flavanones, propolin A and propolin B, isolated and characterized from Taiwanese propolis, induced cytotoxicity effects on human melanoma A2058 cells and showed a strong capability to scavenge free radicals. Markiewicz-Ukowska et al. (2013) also demonstrated that the ethanolic extract of propolis presented cytotoxic properties and may cooperate with temozolomide synergistically enhancing its growth inhibiting activity against glioblastomaU87MG cell lines.

For the protection of human health, considerable attention is currently focused on the consumption of functional foods. In particular, the role of dietary antioxidants capable of scavenging the oxidants and free radicals responsible for initiating various diseases has been intensively discussed (Samarghandian et al., 2013). Systematic investigations of the antioxidant properties of various foods, beverages, spices and herbs have been performed (Samini et al., 2013). Antioxidants are widely used as ingredients in dietary supplements and have been investigated for the prevention of diseases such as cancer, coronary heart disease and even altitude sickness (Baillie et al., 2009). Flavonoids and phenolics are the major complementary compounds of propolis that have beneficial effects as natural antioxidants and prevent oxidative damage of DNA caused by reactive oxygen species (Marghitas et al., 2007). The antioxidant effects may be a result of a combination of radical scavenging and an interaction with enzyme functions. Some components of propolis are absorbed and circulate in the blood and behave as hydrophilic antioxidant and save vitamin $\mathrm{C}$ (Moreira et al., 2008).

The present data have shown that the treatment with propolis alone caused a significant increase in the activities of SOD, TAC, CAT and NO, while decreased the activity levels of GSH at low doses $\mathrm{IC}_{25}$. Also the treatment with low dose of EEP+DOX combination showed an increase in the SOD, TAC, CAT and GSH activity levels, while decreased the NO levels. Also a significant increase in GSH activity levels was detected when cells were treated with $\mathrm{IC}_{25}$ dose of DOX and $\mathrm{IC}_{50}$ dose of EEP respectively. These data are in agreement with the results obtained by Jasprica et al. (2007) who reported that propolis caused a significant reduction in the malondialdehyde (MDA) level and increased the activities of the antioxidant enzymes (SOD, GPx and CAT). The primary mechanism of the effect of propolis may involve the scavenging of free radicals that causes lipid peroxidation. The other mechanism may comprise the inhibiting effect of propolis on the activity of xanthine oxidase, which is known to cause free radicals to be generated (Harris et al. 2000).

Polyphenolic compounds present in propolis have been found to protect erythrocytes from oxidative stress or increase their resistance to damage caused by oxidants. They are able to act as antioxidants in a number of ways, mainly as reducing agents, hydrogen donors, singlet oxygen quenchers, and metal chelating agents. The antioxidant properties of propolis extracts are certainly related to its chemical composition. Many studies 
have evidenced the presence of flavonoids (including flavones, flavonols, flavanones and dihydroflavonols) and other phenolics (mainly substituted cinnamic acids and their esters) as main active constituents of propolis possessing potent antioxidant activities (Valente et al., 2011). Moreover, Marghitas et al. (2009) have shown that propolis samples had significant radical scavenger activities (RSA) where a positive correlation between concentration in total flavonoids and RSA values ( $\mathrm{r} 2=0$, 71) were noticed.

Phenolic compounds are known to counteract oxidative stress in the human body by helping maintaining a balance between oxidant and antioxidant substances (Siddhuraju, 2006). To control the level of reactive oxygen species (ROS) and to protect cells under stress conditions, mammalian tissues contain several enzymes that scavenge ROS such as catalase (CAT) and glutathione-S-transferase (GST). Therefore, during oxidative stress, an increase in the exogenous supply of antioxidants improves the capacity of the tissue to cope with high antioxidant demands such as propolis (Goel et al., 2009). Previous in vitro studies have shown the antioxidant properties of polyphenols and their ability to modulate the activity of various enzymes related to oxidative stress (Sabir et al., 2012). Alyane et al. (2008) demonstrated that antioxidants from natural sources may be useful in the protection of cardio toxicity in patients who receive doxorubicin.

Apoptosis induction is one of the other mechanisms proposed for the anticancer therapeutic effects of propolis (Aso et al., 2004). Apoptosis is a well-characterized type of programmed cell death (PCD) and is considered as a highly regulated process that allows a cell to self-degrade in order to eliminate an unwanted or dysfunctional cell. Conventional anticancer treatments, such as chemotherapy and radiotherapy, kill tumor cells primarily by the induction of apoptosis or apoptosis-like a programmed cell death (Leist and Jaattela, 2001).

The mechanism of cytotoxicity induced by EEP is also of scientific interest. In order to understand the cytotoxic mechanism of EEP in the present study, DNA fragmentation assay was performed for all the studied groups. The data have shown that the untreated control cells had the least DNA breakdown or fragmentation as compared to all the other treatment groups. The DNA of the treated cells showed breakdown which appeared fragmented and sometimes appeared as a mild smear of very small fragments of DNA. It is known that smear bands in DNA gel electrophoresis may reveal some levels of cellular necrosis or could be due to preparation artifacts. However, the obvious differences in the DNA content between the control untreated cells and that of the treated groups during gel electrophoresis indicates that the administered drugs have caused obvious cell death. Our data here is in line with that of Scifo et al. (2004) who pointed out the anticancer activity of resveratrol and propolis extract on human prostate cancer, exerting their cytotoxicity through two different types of cell death: necrosis and apoptosis, respectively.

p53 is an important tumor suppressor gene whose mutation is found in many of human cancers. In response to DNA damage, p53 is activated to induce cell cycle arrest, senescence or apoptosis, through which it prevents proliferation of cells harboring damaged DNA (Vogelstein et al., 2000). Most known target genes of p53 including Bax and p21 have been shown to mediate p53 functions such as cell cycle arrest or apoptosis under genotoxic conditions. Accumulating evidence, however, indicates that another group of target genes do not mediate but inhibit p53 function, thereby acting as negative feedback regulators of p53 (Janicke et al., 2008).

The Bax gene is regulated by p53 and it activates the downstream caspase cascade, eventually resulting in apoptosis. Because the p53 gene product is lost or inactivated by mutation in over $50 \%$ of cancers, the p53 regulates pro-apoptotic genes, including Bax (Takashi, 2009). Cellular stress, including DNA damage, hypoxia and heat-shock, transcriptionally activate p53, which eventually causes G1 arrest via induction of p21cip1. Activation of p53 in response to stress or DNA damage predominantly activates distinct target genes that can either lead to apoptosis, growth arrest or DNA repair. Prolonged stress leads to irreversible DNA damage and eventually triggers the activation of genes involved in the apoptotic pathway including Bax, CD95, NOXA, PUMA and other redox-sensitive genes (Sujoy et al., 2009). The apoptosis pathway is regulated by several factors such as p53 and members of the Bcl-2 protein family. Wild-type p53 protein physiologically acts as a DNAbinding transcription factor and may drive apoptosis as a result of DNA-damaging events (Christine et al., 2001). Members of the Bcl-2 protein family such as Bax, Bak, Bcl-2, and Bcl-XL influence apoptosis or cell cycle entry. When Bax is present in excess, Bax/Bax homodimers are formed, which promote apoptosis. Bax protein is present predominantly in the cytosol, and is able to release cytochrome $\mathrm{C}$ from mitochondria by changes in mitochondrial membrane permeability or electric potential (Atsushi et al., 2001). Release of cytochrome C leads to activation of caspase-9, which then activates caspase-3. Caspases are able to activate DNase and are thus required for the typical DNA fragmentation found in apoptosis (Yasuo et al., 2004).

With cancer being a fatal disease, there have been several efforts to treat cancer using various natural and synthetic materials. Due to problems such as undesirable side effects of chemotherapeutic agents, their drug resistance, complementary and alternative medicine is emerging as a possible solution. Epidemiological data support the concept that naturally occurring anti-cancer agents in the human diet are safe, non-toxic, and have long-lasting beneficial effects on human health (Szliszka et al., 2011). The positive effect of propolis anticancer therapy is seen in its ability to initiate apoptosis in cancer cells through both the intrinsic and extrinsic pathway (Szliszka et al., 2009). The intrinsic apoptotic pathway is mediated by the mitochondria and is mainly controlled by the balance and interactions between pro- and antiapoptotic members of the Bcl-2 family proteins, which regulate the permeability of the mitochondrial membrane (Youle and Strasser, 2008). Both Bax and Bcl-2 genes were shown to increase in expression profile after treatment of the 5637-cell line with Brazilian red propolis (BRP), 
suggesting that Bax and Bcl-2 may be involved in the apoptotic events associated with the cytotoxic effects of BRP (Begnini et al., 2014).

Herein, our study has shown an increase in the p53 gene mRNA expression after treatment with EEP either individually or in combination with DOX. It is well known that p53 contributes to apoptosis induction mostly by its transcription-dependent effects. However, it has been shown that $\mathrm{p} 53$ can also induce cell death via direct activation of Bcl-2, Bcl-XL, and Bax (Chaabane et al., 2013). On the other hand, all treatment compounds used here at all dose levels except that of DOX+EEP at $\mathrm{IC}_{25}$ dose, have exerted a marked increase in the Bax gene mRNA expression levels. The highest Bax gene expression levels were detected in DOX $\left(\mathrm{IC}_{50}\right), \mathrm{EEP}+\mathrm{DOX}\left(\mathrm{IC}_{50}\right)$ and EEP $\left(\mathrm{IC}_{25}\right)$ respectively as compared to the other treatment compounds. These data support our speculation that Egyptian ethanolic extract of propolis may trigger apoptosis or apoptosis-like PCD induction through p53 and Bax activation. EEP at both doses of $\mathrm{IC}_{25}$ and $\mathrm{IC}_{50}$ have activated the expression of P53 gene more than all other treatment compounds after $24 \mathrm{hrs}$.

The data of the present investigation agrees with that previously detected the effect of the propolis preparation (CB propolis) isolated from Brazilian propolis on U937 human histiocytic lymphoma cells (Aso et al., 2004). They found that crude propolis exhibited a dose and time-dependent inhibitory effect on the growth, as well as synthesis of DNA, RNA, and protein in these cells but without obvious antiproliferative effects observed during the first $8 \mathrm{~h}$ of treatment. In a similar fashion, inhibition of synthesis of DNA, RNA, and protein was also observed when the U937 cells were incubated with different doses of propolis (Aso et al., 2004). The authors also demonstrated two very important features of apoptosis, namely, chromatin condensation and DNA fragmentation, although, they did not assay individual caspases to determine their role in the apoptotic process; they however suggested that the propolis-induced apoptosis was mediated via caspase pathways.

Similar findings have been reported in a different leukemia cell line, HL-60. Another Brazilian propolis extracted with water or ethanol was found to inhibit cell growth which was thought to be as a result of direct cytotoxic effect of propolis and induction of granulocytic differentiation in the HL-60 cells. Further, to establish the role of granulocytic differentiation in induction of apoptosis, features such as nuclear condensation and fragmentation, as well as DNA ladder formation were looked for under fluorescence microscope and were found to be present, hence, confirming that the apoptosis was partly mediated by granulocytic differentiation of HL-60 cells (Mishima et al., 2005). These findings were confirmed and even further elaborated by the work of Motomura et al. (2008), which provided additional information on the mechanism of propolis-induced apoptosis by examining the expression of antiapoptotic and proapoptotic proteins. They demonstrated that incubation of human leukemic U937 cells with methanolic extract of propolis resulted in decreasing the expression of Bcl-2 (antiapoptotic protein) in a dose-dependent manner. On the basis of
Antitumor Effects of Propolis Against PC3 Prostate Cancer Cells

this, they suggested that the apoptotic cell death induced by propolis was mediated by mitochondrial mechanism. Furthermore, they observed a dose-dependent decrease in the concentration of procaspase- 3 which suggested that there was activation of caspase- 3 by propolis. Incubation of the U937 cells with 300 and $500 \mathrm{mg}$ propolis was also demonstrated to cause cell cycle arrest as evidenced by up-regulation of expression of p21 and p27 and downregulation of expression of cyclin $\mathrm{A}$, cyclin $\mathrm{B}, \mathrm{Cdc} 2$, and $\mathrm{Cdk} 2$, all of which are believed to play a key role in cell cycle and apoptosis (Motomura et al., 2008).

In conclusion, the present study has shown the potency of EEP on inhibiting prostate cancer cells in vitro. The mechanism of action is clearly shown to be through antioxidant pathways and through induction of apoptosis as indicated by increasing the expression of p53 and the proapoptotic gene, Bax.

\section{Acknowledgements}

The authors wish to thank the Centre of Excellence in Scientific Research (CESR) of the Faculty of Veterinary Medicine (funded by management supporting excellence (MSE)-Egypt and Benha University), Dr. Ahmed Kamel Aly, of the Plant Protection Institute, Agriculture Research Centre, Dokky Cairo, Dr. Eman Manaa of the Faculty of Veterinary Medicine, Benha University and the staff members of the Central Laboratory of Tanta University for their kind help and support.

\section{References}

Abd El-Hady FK, Hegazi AG (1994). Gas chromatography -mass spectrometry (GC/MS) study of the Egyptian propolis 1-aliphatic, phenolic acids and their esters. Egypt J Appl Sci, 9, 749-60.

Abozid MM, Ahmed AA (2013). Chemical composition of Egyptian and commercial propolis and its effects on liver function and lipid profiles in albino rats. J Biological Chem. Env Res, 8, 323-40.

Adams JM, Cory S (1998). The bcl-2 protein family, Arbiters of cell survival. Science, 281, 1322-6.

Akyol S, Ugurcu V, Balci M, et al (2014). Caffeic acid phenethyl ester, its protective role against certain major eye diseases. J Ocul Pharmacol Ther, 30, 700-8.

Alyane M,Kebsa LB, Boussenane H, et al (2008). Cardioprtective effects and mechanism of action of poly phenols extracted from propolis against doxorubicin toxicity. Pak J pharm Sci, 1, 20-9.

Aso K, Kanno S, Tadano T, et al (2004). Inhibitory effect of propolis on the growth of human leukemic U937. Biol Pharm Bull, 27, 727-30.

Atsushi K, Mutsuo F, Manabu M, et al (2001). Expression of Bax and apoptosis-related proteins in human esophageal squamous cell carcinoma including dysplasia. Canadian Academy Pathol, 14, 741-7.

Baillie JK, Thompson AAR, Irving JB, et al (2009). Oral antioxidant supplementation does not prevent acute mountain sickness, double blind randomized placebocontrolled trial. QJM, Int J Med, 102, 341-8.

Begnini KR, Moura de Leon PM, Thurow H, et al (2014). Brazilian red propolis induces apoptosis-like cell death and decreases migration potential in bladder cancer cells. Evid Based Complement Alternat Med, 2014, 639856. 
Beutler E, Dunning D, Dabe IB, et al (1988). Erythrocyte glutathione S-transferase deficiency and hemolytic anemia. Blood, 72, 73-7.

Chaabane W, User SD, El-Gazzah M, et al (2013). Autophagy, apoptosis, mitoptosis and necrosis, interdependence between those pathways and effects on cancer. Arch Immunol Ther Exp (Warsz), 61, 43-58.

Chan GC, Cheung KW, Sze DM.(2013). The immunomodulatory and anticancer properties of propolis. Clin Rev Allergy Immunol, 44, 262-73.

Chen CN, Wu CL, Lin JK (2007). Apoptosis of human melanoma cells induced by the novel compounds propolin $\mathrm{A}$ and propolin B from Taiwenese propolis. Cancer Lett, 245, 218-31.

Chen MJ, Chang WH, Lin CC, et al (2008). Caffeic acid phenethyl ester induces apoptosis of human pancreatic cancer cells involving caspase and mitochondrial dysfunction. Pancreatol, 8, 566-76.

Christine ME, Martine FR, Stanley JK, et al (2001). Bax loss impairs myc-induced apoptosis and circumvents the selection of p53 mutations during myc-mediated lymphomagenesis. Mol Cell Biol, 21, 7653-62.

Daugsch A, Moraes CS, Fort P, et al (2008). Brazilian red propolis chemical composition and botanical origin. Evid Based Comp Alternat Med, 5, 435-41.

Goel M,Eraslan G, Silici S (2009). Antioxidant effect of propolis against exposure to propetamphos in rats. Ecotoxicol. Environ Safety, 72, 900-915.

Harris SR, Panaro NJ, Thorgeirsson UP (2000). Oxidative stress contributes to the anti-proliferative effects of flavone acetic acid on endothelial cells. Anticancer Res, 20, 2249-54.

Hilger RA, Richly H, Grubert M, et al (2005). Pharmacokinetics (PK) of a liposomal encapsulated fraction containing doxorubicin and of doxorubicin released from the liposomal capsule after intravenous infusion of Caelyx/Doxil. Int J Clin Pharmacol Ther, 43, 588.

Janicke RU, Sohn D, Schulze-Osthoff K (2008). The dark side of a tumor suppressor, anti-apoptotic p53. Cell Death Differ, 15, 959-76.

Jasprica I, Mornar A, Debeljak Z, et al (2007). In vivo study of propolis supplementation effects on antioxidative status and red blood cells. J Ethnopharmacol, 110, 548-54.

Kasala ER, Bodduluru LN, Madana RM, et al (2015). Chemopreventive and therapeutic potential of chrysin in cancer, mechanistic perspectives. Toxicol Lett, 233, 214-25.

Khalil ML (2006). Biological activity of bee propolis in health and disease, Asian Pac J Cancer Prev, 7, 22-31.

Kimoto T, Arai S, Kohguchi M, et al (1998). Apoptosis and suppression of tumor growthby artepillin $\mathrm{C}$ extracted from Brazilian propolis. Cancer Detect Prev, 22, 506-15.

Kimoto T, Aga M, Hino K, et al (2001). Apoptosis of human leukemia cells induced by Artepillin $\mathrm{C}$, an active ingredient of Brazilian propolis. Anticancer Res, 21, 221-8.

Kujumgiev A, Tsvetkova I, Serkedjieva Y, et al (1999). Antibacterial, antifungal and antiviral activity of propolis of different geographic origin. J Ethnopharmacol, 64, 235-240.

Kumazawa S, Hamasaka T, Nakayama T. (2004). Antioxidant activity of propolis of various geographic origins. Food Chem, 84, 329-39.

Leist M, Jaattela M (2001). Four deaths and a funeral, from caspases to alternative mechanisms. Nature Rev Molecular Cell Biol, 2, 589-98.

Marghitas LA, Laslo L, Dezmirean D, et al (2007). Total phenolics and antioxidant activity of romanian propolis. international conference agricultural and food sciences, progresses and technologies, sibiu, romania, 209-12.

Marghitas AL, Dezmirean D, Moise A, et al (2009). DPPH method for evaluation of propolis antioxidant activity. Bulletin UASVM Animal Sci Biotechnol, 66, 253-8.

Markiewicz-Ukowska R, Borawska MH, Fiedorowicz A, et al (2013). Propolis changes the anticancer activity of temozolomide in U87MG human glioblastoma cell line. BMCComplement Altern Med, 13, 50.

Mishima S, Narita Y, Chikamatsu S (2005). Effects of propolis on cell growth and gene expression in HL-60 cells. $J$ Ethnopharmacol, 99, 5-11.

Montgomery JF, Hum S (1995). Field diagnosis of nitrite poisoning in cattle by testing aqueous humour samples with urine test strips. Vet Rec, 137, 593-4.

Moreira L, Dias LG, Pereira JA, et al (2008). Antioxidant properties, total phenols and pollen analysis of propolis samples from Portugal. Food Chem Toxicol, 46, 3482-85.

Motomura MK, Won KM, Suh SJ, et al (2008). Propolis induces cell cycle arrest and apoptosis in human leukemic U937 cells through Bcl-2/Bax regulation. Environ Toxicol Pharmacol, 26, 61-7.

Murtaza G, Karim S, Akram MR, et al (2014). Caffeic acid phenethyl ester and therapeutic potentials. Biomed Res Int, 145342, 9 .

Orsatti CL, Missima F, Pagliarone AC, et al (2010). Propolis immunomodulatory action in vivo on Toll-like receptors 2 and 4 expression and on pro-inflammatory cytokines production in mice. Phytotherapy Res, 24, 1141-6.

Orsolic N, Horvatknezevic A, Benkovic V, et al (2008). Benefits of use of propolis and related flavonoids against the toxicity of chemotherapeutic agents. in orsolic, n; basic, i (eds). ethnopharmacology- review book. Res Signpost India, 195-222.

Orsolic N (2010). A review of propolis antitumour action in vivo and in vitro. J Api Productand Ap Med Sci, 2, 1-20.

Quinn M, Babb P (2002). Patterns and trends in prostate cancer incidence, survival, prevalence and mortality. Part I, International comparisons. BJU Int, 90, 162-73.

Sabir SM, Ahmad SD, Abdul H, et al (2012). Antioxidant and Hepatoprotective activity of ethanolic extract of leaves of Solidago microglossa containing polyphenolic compounds. Food Chem, 131, 741-7.

Salim EI, Jazieh AR, Moore MA (2011). Lung cancer incidence in the Arab league countries, risk factors and control. Asian Pac J Cancer Prev, 12, 17-34.

Samarghandian S, Shabestari MM (2013). DNA fragmentation and apoptosis induced by safranal in human prostate cancer cell line. Indian J Urol 29, 177-83

Samarghandian S, Borji A, Delkhosh MB, et al. (2013). Safranal treatment improves hyperglycemia, hyperlipidemia and oxidative stress in streptozotocin-induced diabetic rats. $J$ Pharm Pharm Sci, 16, 352-62.

Samini F, Samarghandian S, Borji A, et al (2013). Curcumin pretreatment attenuates brain lesion size and improves neurological function following traumatic brain injury in the rat. Pharmacol Biochem Behav, 110, 238-44.

Scheller S, Krol W, Swiacik J, et al (1989). Antitumoral property of ethanolic extract of propolis in mice-bearing Ehrlich carcinoma, as compared to bleomycin. $Z$ Naturforsch $C$, 44, 1063-5.

Scifo C, Cardile V, Russo A, et al (2004). Resveratrol and propolis as necrosis or apoptosisinducers in human prostate carcinoma cells. Oncol Res, 14, 415-26.

Shiraishi N, Inai Y, Bi W, Nishikimi M (2005). Fragmentation and dimerization of copper-loaded prion protein by coppercatalysed oxidation. Biochem J, 387, 247-55.

Siddhuraju P (2006). The antioxidant activity and free radicalscavenging capacity of phenolics of raw and dry heated moth bean. (Vigna aconitifolia) (Jacq.) Marcchal seed extracts, 
99, 149-57.

Sinha BK, Trush MA, Kennedt KA, et al (1984). Enzymatic activation and binding of adriamycin to nuclear DNA. Cancer Res, 44, 2892.

Skehan P, Storeng R, Scudiero D, et al (1990). New colorimetric cytotoxicity assay for anticancer-drug screening. $J$ Nat Cancer Instit, 82, 1107-12.

Sujoy B, Ramesh MR, Leonard RJ (2009). Role of polyamines in p53-dependent apoptosis of intestinal epithelial cells. Cellular Signalling, 21, 509-22.

Szliszka E, Czuba ZP, Domino M, et al (2009). Ethanolic extract of propolis (EEP) enhances the apoptosis-inducing potential of TRAIL in cancer cells. Molecules, 14, 738-54.

Szliszka E, Czuba ZP, Bronikowska J, et al (2011). Ethanolic extract of propolis augments TRAIL-induced apoptotic death in prostate cancer cells. Evid Based Complement Alternat Med, 2011, 535172

Takashi S (2009). Zinc-finger-based artificial transcription factors and their applications. Advanced Drug Delivery Reviews, 43, 8510-615.

Taraswi B, Somsubhra N, Susanta R (2009). DNA damage induced $\mathrm{p} 53$ down regulates $\mathrm{Cdc} 20$ by direct binding to its promoter causing chromatin remodeling. Nucleic Acids Res, 10, 1-11.

Teixeira EW, Message D, Negri G, et al (2010). Seasonal variation, chemical composition and antioxidant activity of Brazilian propolis samples. Evid Based Comp Alter Med, 7, 307-15.

Yong YK, Tan JJ, The SS, et al (2013). Clinacanthus nutans extracts are antioxidant with antiproliferative effect on cultured human cancer cell lines. Evid Based Complement Alternat Med, 2013, 462751

Youle RJ, Strasser A (2008). The BCL-2 protein family, opposing activities that mediate cell death. Nature Reviews Mol Cell Biol, 9, 47-59.

Zand RS, Jenkins DJ, Diamandis EP (2000). Steroid hormone activity of flavonoids and related compounds. Breast Cancer Res Treat, 62, 35-49.

Valente MJ, Baltazar AF, Henrique R, et al (2011). Biological activities of portuguese propolis, protection against free radical-induced erythrocyte damage and inhibition of human renal cancer cell growth in vitro. Food Chem. Toxicol, 49, 86-92.

Vatansever HS, Sorkun K, Gurhan SID (2010). Propolis from Turkey induces apoptosis through activating caspases inhuman breast carcinoma cell lines. Acta Histochemica, 112, 546-56.

Vogelstein B, Lane D, Levine AJ (2000). Surfing the p53 network. Nature, 408, 307-10.

Yagmurca M, Erdogan H, Iraz M, et al (2004). Caffeic acid phenethyl ester as a protective agent against doxorubicin nephrotoxicity in rats. Clin Chim Acta, 348, 27-34.

Yasuo T, Nobuyuki A, Shinsuke I, et al (2004). Loss of caspase-8 activation pathway is a possible mechanism for CDDP resistance in human laryngeal squamous cell carcinoma HEP-2 cells. International J Oncol, 25, 721-8. 